\title{
CONTRIBUIÇÃO AO ESTUDO DA ÚLCERA PÉPTICA POST-OPERATÓRIA
}

\section{DR. EDGARD PINTO DE SOUZA}

(Assistente voluntário)

\section{DDO. ROLDÃO CONSONI}

(Estudante efetivo)

O presente trabalho é baseado em 7 casos de úlcera péptica post-operatória, da clínica hospitalar do Prof. Correia Neto na 3. ${ }^{\text {a }}$ C. H. da Santa Casa de São Paulo, onde somos assistentes.

As úlceras pépticas post-operatórias podem ser consideradas como uma das complicações mais importantes da cirurgia gástrica.

Podem sobrevir após uma simples gastro-enterostomia (G.E.), ou depois de gastrectomias. Dos nossos 7 casos, 6 foram consequentes a G.E. e um a gastrectomia. Tal incidência, porém, é maior após as G.E. que após as gastrectomias.

No que diz respeito à frequência das úlceras pépticas postgastro-enterô, encontramos na literatura os números os mais contraditórios, variando a frequência desde 1,2\% (estatística de Balfour baseada em 8.600 G.E. com sòmente 270 casos) e $34 \%$ (estatística de Lewisohn, que em $68 \mathrm{G} . \mathrm{E}$. encontrou 23 úlceras pépticas postoperatórias). Esta variabilidade na incidência talvez seja consequente a um sistema não uniforme de registro e de observação cuidadosa dos doentes. Todos os A.A., porém, são concordes no afirmar que as úlceras pépticas post-operatórias são mais frequentes após as G. E. por úlcera duodenal que por úlcera gástrica.

A formação de úlcera péptica post-operatória após gastrectomia constitue eventualidade muito mais rara. Starlinger reuniu 25.647 casos de gastrectomias executadas pelas técnicas as mais variadas, onde se verificou ulceração péptica post-operatória em 173 casos, portanto uma porcentagem de incidência muito baixa $(0,7 \%)$.

Etiologia - Como diz Leriche, a etiologia da úlcera péptica post-operatória confunde-se com a da úlcera gastro-duodenal. Constituindo a etiologia desta última, um problema ainda não resolvido satisfatòriamente, somos obrigados a concluir que a etiologia da úlcera péptica post-operatória ainda nos escapa. Não existe um elemento que possa ser incriminado como o único responsável, mas sim um conjunto de fatores que podem ser considerados como tais. São: 


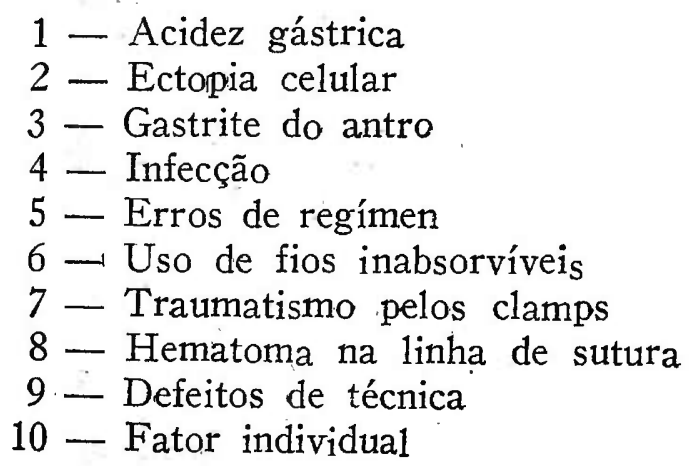

Cada um dêstes fatores merece um estudo especial; entretanto, para não nos alongarmos muito, e por não estarem as idéias ainda definitivamente esclarecidas, deixaremos de lado êste capítulo; adiantando, porém, que, de todos os agentes citados como responsáveis, os que na realidade devem ser levados em consideração são: 1 - acidez; 2 - a teoria da ectopia celular (ilhotas epiteliais que se encontram ao longo do tubo digestivo è que são constituidas por tecidos que apresentam os caracteres da mucosa gástrica e que são então suscetíveis de produzir no segmento intestinal em que se assentam, lesões idênticas às das úlceras gastro-duodenais); 3 - gastrite do antro; 4 - os defeitos de técnica (indicação operatória mal feita, bôca mal colocada ou mal orientada, ressecção insuficiente, etc.) ; 5 - fator individual (predisposição ulcerosa).

Sintomatologia - Os primeiros sintomas da úlcera péptica post-operatória podem aparecer do segundo dia até 15 anos após a operação. Na maioria das vezes, porém, começam êles a se manifestar no decorrer do $1 .^{\circ}$ ou $2 .^{\circ}$ ano de post-operatório.

Nos nossos 7 casos, as datas de aparecimento das primeiras perturbações foram as seguintes: das 6 úlceras jejunais consequentes a G.E., num $1 .^{\circ}$ caso os sintomas surgiram semanas após a intervenção; em 3 outros, 6 meses após; em um outro, 3 anos mais tarde; e finalmente no último, sòmente 10 anos após a operação. No único caso de úlcera péptica post-operatória post-gastrectomia, os primeiros incômodos surgiram 3 anos após a operação.

De todos os sintomas que oferecem os pacientes portadores de úlcera péptica post-operatória, o mais importante é a dôr. E' uma dôr violenta e em geral muito mais intensa que a das úlceras gástricas e duodenais, que dificilmente céde com os processo habituais, só se deixando influenciar pela morfina. São quasi sempre dôres do tipo tardio, surgindo 4 a 5 horas após a ingestão de alimentos; podem, porém, aparecer precocemente. Quando o, paciente não se alimenta e permanece em jejum, elas não aparecem.

A princípio os períodos dolorosos apresentam uma variação de mais ou menos 10 dias a 1 mês e são separados por intervalos variáveis. Com o progredir da moléstia, as dôres sobrevêm mais frequentemente, chegando mesmo a ser diárias. 
Quanto à localização da dôr, encontra-se ela em nível nuais baixo que a das úlceras gastro-duodenais, e quasi sempre à esquerda do umbigo e abaixo do mesmo.

Esta dôr espontânea tem, porém, pouco valor, pois pode ter outra localização que não a epigástrica ou mesmo estar ausente. Muito mais importante para o diagnóstico é a dôr provocada, haven'do mesmo quem afirme que todo diagnóstico de úlcera péptica post-operatória sem dôr à pressão, deve ser admitido com grandes reservas. A palpação do abdômen torna-se pois indispensável; em geral sentimos à grandé curvatura do estômago e palpamos, à esquerda da/linha mediana, a bôca anastomótica sob a forma de um cordão duro, transversal, e conseguimos então provocar neste ponto, pela pressão digital, dôr de maior ou menor intensidade.

O vômito é, depois da dôr, o fenômeno mais característico. No entretanto, é êle menos frequente que nas úlceras gastro-duodenais. Aparece em geral no final da crise dolorosa, produzindo quasi sempre uma fase de acalmia. Quando êle é fecalóide, devermos imediatamente pensar em perfuração da úlcera no cólon transverso.

Quanto à hematemese, constitue ela um sintoma excecional, mesmo porque, em muitos casos, é difícil dizer se o sangue provém de uma úlcera péptica. post-operatória ou de uma úlcera antiga que não se cicatrizou.

As hemorragias pelo tubo intestinal (melena) são igualmente raras.

Quando a úlcera péptica, em sua evolução, perfura no cólon transverso, origina-se a chamada fístula gastro-jejuno-cólica. Nos nossos 7 casos, verificou-se esta complicação uma única vez. Tratavase de um rapaz de 28 anos de idade, que após suportar por 8 anos todos os sintomas clássicos da úlcera duodenal, foi operado em São Carlos, onde the executaram uma gastro-êntero-anastomose. A operação, porém, não lhe trouxe nenhuma melhora, nem ao menos imediata. Continuaram as dôres, azia, vômitos, etc. Aproximadamente 4 anos após a operação, verificou-se uma agravação da doença; após as refeições passou a sentir insuportável tenøão no epigástrio e região umbilical, e 15 a 20 minutos após a ingestão, evacuava os alimentos recém-ingeridos íntegros, sem digestão. Êste sintoma foi suficiente para permitir o diagnóstico de fístula-gastro-jejuno-cólica, que os R.X. confirmaram.

Caracteriza-se esta afecção por 4 sintomas cardeais: diarréia, eructações fétidas, vômitos fecalóides e dôres.

A diarréia é o sintoma mais importante; é desde o início abundante, 8, 10, 20 evacuações diárias. Fator fundamental é que, imediatamente após a ingestão os alimentos, não digeridos, passam para o cólon transverso e se eliminam pelo reto. Este sintoma é patrgnomônico e exclusivamente êle nos permitiu firmar, no nosso caso, o diagnóstico de fístula gastro-jejuno-cólica.

As eructações fétidas encontram-se igualmente com grande frequência; desprendem um cheiro de ovo podre e de excrementos e 
se acompanham de um gộsto horrível na bôca. Eram ausentes no nosso caso.

Os vômitos são em geral abundantes e de gôsto muito desagradável. Apresentam-se sob a forma de um mingáu enegrecido, e a sondagem gástrica retira detritos de fezes.

As dôres podem ser discretasi ou muito intensas. São devidas a dois fatores: $10^{\circ}$ - à úlcera péptica, $20^{\circ}$ - à oclusão parcial do cólon transverso. As dôres consequentes à úlcera jejunal se assestam na vizinhança do umbigo e com o máximo de inténsidade à esquerda do mesmo e se irradiam para o flanco esquerdo. As devidas à oclusão parcial do cólon têm lugar na parte inferior do abdômen e se acompanham de meteorismo com onda peristáltica visível na superfície do abdômen.

Diagnóstico - O diagnóstico clínico da úlcera péptica postoperatória, é em geral difícil. Quando um doente que sofreu uma gastro-enterostomia começa a apresentar sintomas, várias hipóteses podem ser aventadas. $E^{\prime}$ assim que pode tratar-se: 1 - de uma úlcera primitiva, gástrica ou duodenal, que não cicatrizou; 2 - de aderências post-operatórias; 3 - de transformação neoplásica da primitiva úlcera; 4 - de perturbações que têm origem na bôca anastomótica, que se apresenta por exemplo estenosada, ocasionando estase gástrica; de gastrite, etc. A anamnese, se bem que de grande valia, em geral não é suficiente para a feitura do diagnóstico. O exame físico nos dá poucos dados; pela palpação comprova-se a existência de uma zona dolorosa na região do umbigo e em geral à esquerda do mesmo. O exame químico do suco gástrico (prova de Katsch-Kalk) não constitue igualmente uma prova segura de diagnóstico. O material retirado do estômago apresenta-se sempre corado pela bile e o contetido gástrico encontra-se constantemente neutralizado. Nos nossos 7 casos, executamos a prova de Katsch-Kalk em 4 pacientes, gastro-enteromizados anteriormente; num havia hiperacidez e nos demais hipo-acidez.

O meio de diagnóstico mais seguro é, sem dúvida, o radioscópico e radiográfico, sendo que em determinados casos a certeza absoluta só é dada pela comprovação operatória.

Complicações - As mais frequentes são: hemorragia, perfuração, estenose, e fístula gastro-jejuno-cólica.

No que diz respeito à perfuração, devemos dizer que, embora constitua uma das complicações mais graves, é de frequência relativamente rara, verificando-se numa porcentagem de incidência visìvelmente inferior à correspondente às ulceras gastro-duodenais primitivas. Os sintomas da úlcera péptica post-operatória perfurada, assemelham-se aos clássicos da úlcera gástrica ou duodenal que se perfura, isto é, dôr em punhalada no epigástrio, defeza exagerada da parede abdominal que se apresenta sob a fórma de ventre de madeira, pulso acelerado, queda da pressão, choque, pneumoperitônio 
e desaparecimento da macissez hepática; finalmente, numa fase mais avançada, surgem os sintomas de peritonite generalizada franca.

A hemorragia constitue complicação ainda mais rara que a perfuração.

A estenose da bôca anastomótica é, no entanto, relativamente frequente, parecendo ser devida a uma esclerose retrátil do tipo cicatricial.

Finalmente, o último tipo de complicação, sem dúvida mais grave, a fístula gastro-jejuno-cólica, apresenta-se, segundo a estatítica da Mayo Clinic, em 2,36\% das úlceras pépticas post-operatórias. No entanto Gosset, relator oficial do Congresso Francês de Cirurgia de 1930, relata uma incidência muito mais elevada; é assim que, num total de 289 úlceras pépticas post-operatórias, encontra 35 fístulas gastro-jejuno-cólicas, ou seja uma frequência de $12 \%$. O mesmo se diga de Labandibar, da Argentina, que sôbre um total de 238 observações, encontra 31 fístulas gastro-jejuno-cólicas, ou seja $13,6 \%$ de incidência, Dos nossos 7 casos, apenas um apresentava perfuração no cólon transverso, o que dá uma incidência de $14,3 \%$.

Tratamento - O tratamento da úlcera péptica post-operatória é essencialmente cirúrgico. Foram propostas pelos autores diversas modalidades de intervenções; a experiência se incumbiu de, paulatinamente, eliminar as operações parciais pelas suas grandes desvantagens. Concomitantemente, foi ganhando terreno a intervenção radical: a gastrectomia parcial. Retirando a úlcera e a gastrite infecciosa, a gastrectomia parcial veiu solucionar o problema de modo até certo ponto satisfatório, pelo menos no estado atual dos nossos conhecimentos. Releva ponderar que a operação é sobremodo grave, exigindo conhecimento perfeito da cirúrgia abdominal. Entre nós foi ela pela primeira vez executada em 1929 pelo Prof. Correia Neto (Bol. Soc. Med. Cir. São Paulo 13 (10) : 423; Dez. 1929).

Técnica - Descrevemos a seguir, em linhas gerais, a técnica da gastrectomia parcial para a úlcera péptica post-operatória, postgastro-enterô, empregada no Serviço.

Anestesia - Peridural, sendo usada solução de novocaina a $2 \%$, preparada no momento, na quantidade de 55 a 60 cc., com adição de $\mathrm{X}$ gotas de adrenalina. Punção preferivelmente entre D12 - L1. Zerbini publicou, em 1938, a técnica adotada no Serviço, para esta anestesia. (Rev. Cir. S. Paulo, Dez. 1938).

Incisão - Mediana, xifo-umbilical. Se a incisão anterior tiver sido mediana, a atual é feita fusiforme, de modo a ser ret rada a cicatriz anterior. A aponevrose da linha branca é exposta e incisada de alto a baixo. Descolamento, em pequena extensão, e de cada lado, da face posterior da aponevrose da linha branca. Abertura 
do peritônio. Colocação do afastador de Gosset e da válvula de Balfour.

Libertação de órgãos - Uma vez aberta a cavidade peritonial, torna-se necessário seccionar todas as aderências, sempre numerosas, e que prendem o estômago, o fágado, a vesícula biliar, o peritônio parietal, o cólon transverso, etc., de modo a se conseguir uma perfeita individualização dêsses órgãos. E' feito então um exame do processo operatório anteriormente realizado, das condições atuais das estruturas que mais interessam ao caso, e da localização da úlcera jejunal.

Desinserção colo-epiplóica - Praticada a bisturí, em zona avascular, a desinserção não determina sangramento. A separação entre o grande epíploon e o cólon transverso permite que penetremos amplamente na retrocavidade dos epíploons.

Libertação da neostomia - Êste tempo é geralmènte trabalhoso, pelo grande número de aderências formadas ao redor da bôca anastomótica, as quais mascaram as estruturas anatômicas circumvizinhas. Progredindo com muita cautela, chega-se a isolar completamente a bôca anastótica do mesocólon transverso, a que fôra anteriormente fixada.

Ressecção do segmento jejunal anastomosado - Passa.-se agora ao tempo intestinal propriamente dito. O jejuno é amarrado de cada lado da neostomia, e à distância de cêrca de $5 \mathrm{cms}$. da mesma, com fio de catgut 1 . Um clamp de coprostase é colocado para fóra de cada uma das ligaduras citadas; em seguida, pratica-se' a secção da alça jejunal. Desinfecção das aberturas intestinais ; panos estéreis para proteção. Ligadura dos vasos do mesentério.

Jejuno-jejunostomia - O restabelecimento do trânsito intestinal é feito por meio de uma anastomose término-terminal en 2 planos, com catgut cromado 0 . A bôca anastomótica e o segmento jejunal ressecado são tracionados, através da brecha mesocólica, para o andar supra-mesocólico. Está terminado, por conseguinte, o tempo intestinal da operação; o tempo gástrico, que se segue, resume-se numa gastrectomia típica, a-Reichel Polya.

Ligadura dos ramos gástricos da artéria gastro=epiplóica direita - Exposto o ligamento gastro-cólico e identificada a artéria gastro-epiplóica direita, o cirurgião, em ponto baixo da grande curvatura, e rente à mesma, transfixa com uma pinça de Kocher o ligamento gastro-cólico, e coloca duas pinças de Kocher de modo a apanhar alguns ramos retos, os quais são a seguir seccionados. E assim progride-se sucessivamente da direita para a esquerda, até se atingir o ponto em que a gastro-epiplóica direita se anastomosa com 
a esquerda. Agora, com catgut simples 0, são ligados todos os vasos pinçados. Inferiormente, progride-se até à primeira porção do duodeno, fazendo-se ligaduras após pinçamento e secção. Êste tempo pode ser muito delicado pela possibilidade da existência de uma úlcera duodenal primitiva em evolução, em estado de latência, ou mesmo cicatrizada, o que, de qualquer modo, importa na existência de maior ou menor número de aderências e retrações.

Ligadura da artéria pilórica - Através de uma brecha praticada no pequeno epíplon, introduzem-se dois Kochers longos, que pinçam o pequeno epíplon na parte onde passa a artéria pilórica. Secção e ligadura da mesma com catgut cromado n. ${ }^{\circ} 2$.

Ligadura e secção do duodeno em nivel inferior ao processo ulceroso (caso êste exista) sepultamento do coto duodenal O duodeno, uma vez liberado em extensão conveniente, é esmagado, e nêste ponto ligado com catgut simples 2, dando-se duas voltas ao redor do mesmo. Secção do duodeno; desinfecção e sepultamento do coto duodenal por meio de uma sutura em bolsa com catgut simples 1, ou do ponto em $\mathrm{N}$ do Prof. Correia Neto.

Ligadura da artéria coronária - Esta ligadura é feita com catgut cromado 2 , num ponto situado imediatamente acima da linha de secção do estômago. Apresentado o estômago pelo cirurgiãs. o assistente, com uma pinça de Kocher e por meio de movimentos de divulsão, vai penetrando até transfixar completamente o pequeno epíplon, ficando de um lado a artéria coronária, geralmente já bifurcada, e de outro lado a pequena curvatura. À ponta do Koche:, é apresentado o fio duplo. Fazem-se as duas ligaduras e secciona-se.

Fixação do lábio esquerdo da brecha mesocólica na face posterior do estômago - São dados pontos separados, com catgut simples 0 ; em geral 3 ou 4 pontos são suficientes.

Gastro-jejunostomia - O trânsito é restabelecido por meio de uma anastomose término-gástrica látero-jejunal praticada a juzante da jejuno-jejunostomia. Sutura em 2 planos, com catgut cromado 0 ; agulhas atraumáticas.

Fixação do lábio direito da brecha mesocólica na face anterior do estômago - Sutura em pontos separados, com catgut simples 0 .

Fechamento da parede - O fechamento é feito por planos. Pratica-se o embricamento aponerrótico da linha liranca, pela técnica do Prof. Correia Neto. 
Tal é a técnica adotada no Serviço, para as úlceras pépticas consequentes a uma G.E. No caso da operação primitiva ter sido uma gastrectomia a Reichel-Polya e não uma G.E., a técnica operatória é um pouco diversa; o descolamento inter-colo-epiplóico já não mais é necessário, e o tempo de ligadura da artéria pilórica, bem como o isolamiento, ligadura e secção do duodeno, estão afastados. A sequênc:a operatória é, então, em linhas gerais, a seguinte: uma vez aberto o ventre e desfeitas as adesões que prendem o estômago aos órgãos vizinhos, desfaz-se, à tezoura, as aderências existentes entre o lábio direito da janela mesocólica, e a face anterior do estômago. Em seguida são levantados o cólon transverso e o grande epíploon, que são mantidos por um auxiliar, e libertam-se, pelo andar infra-mesocólico, as aderências entre o lábio esquerdo da janela mesocólica e a face posterior do estômago. Uma vez libertado todo o contôrno da bôca anastomótica, da brecha mesocólica, procede-se à ligadura dos vasos gástricos entre a grande curvatura e a arcada das gastro-epiplóicas. A artéria coronária estomáquica é agora ligada num nível pouco superior ao da secção gástrica. Estando então libertados o estômago e a bôca anastomótica, é esta última trazida para o andar supra-mesocólico, iniciando-se agora o tempo intestinal, onde o jejuno é amarrado a montante e a juzante da neostomia e a cêrca de $5 \mathrm{cms}$. de distância da mesma, com catgut simples n.$^{\circ} 1$. Un clamp de coprostase é colocado ao lado de cada uma das ligaduras citadas, e a alça jejunal, é seccionada a montante e a juzante da anastomose gastro-jejunal, entre as ligaduräs e os clamps. Assepsia das aberturas intestinais com iodo, ligadura dos vasos do mesentério e secção do mesmo.

O restabelecimento do trânsito intestinal é feito por intermédio duma anastomose jejuno-jejunal término-terminal em dois planos, com catgut cromado zero montado em agulha atraumática. Segue-se agora o tempo gástrico da operação, que cifra-se numa anastomose término-gástrica látero-jejunal feita a juzante da anastomose jejunojejunal. A peça operatória ressecada consta pois, dum pequeno segmento do estômago, ao qual está apenisa a bôca anastomótica primitiva e dois pequenos segmentos de jejuno.

A operação é terminada suturando-se o lábio direito da brecha mesocólica na face anterior do estômago (o lábio esquerdo já está suturado à face posterior do estômago, manobra esta que foi executada antes de se colocarem os clamps de Abbadie) e fechando-se a parede em 3 planos.

Em face duma fístula gastro-jejuno-cólica, além da ressecção do jejuno, torna-se igualmente necessária, a extirpação de um segmento de cólon transverso, o que torna a operação muito mais difícil e muito mais grave. Afim de evitar o perigo da deiscência da colocolostomia término-terminal, póde-se praticar a operação em dois tempos. Num primeiro tempo faz-se a ressecção de um segmento de jejuno seguida de anastomose jejuno-jejunal e a anastomose 
gastro-intestinal. Os dois cotos do cólon transverso são derivados para o exterior, adiando-se a sua reconstituição para um segundo tempo operatório. Há quem preconize, nos casos muito avançados de moléstia onde então as condições gerais do doente são más, a execução da intervenção em 3 tempos. O $10^{\circ}$ consta numa jejunostomia destinada a alimentar e hidratar o paciente, e os 2 seguintes se assemelham aos descritos para a operação em 2 tempos.

Finalmente podemos nos deparar com uma úlcera péptica postgastrectom:a pré-cólica com jejuno-jejuno anastomose de Braun, operação esța muito preconizada por certos cirurgiões alemães, entre êles Gohrbandt, que a reputam superior à técnica de Reichel-Polya. A gastrectomia parcial nestes casos, é mais ou menos semelhante à que se faz para a úlcera post-gastrectomia a Reichel-Polya, com a diferença de que aqui, não existe o complexo e difícil tempo da libertação da anastomose gastro-jejunal da brecha mesocólica.

\section{O B S E R V A Ç O E S}

\section{OBSERVAÇÃO N. N $^{\circ}$}

A. N., 29 anos, branco, 'brasileiro, casado, guarda-civil.

História pregressa da moléstia atual: Em Maio de 1932, começou a sentir, após as refeições, pêsò no epigástrio. Dentro de algumas semanas, a sensação de pêso foi substituida por dôr epigástrica, que mantinha relação estreita com a alimentação, aparecendo 3 a 4 horas após as refeições. Surgiram também vômitos, azias, melenas. Tinha períodos de acalmia, sendo de 3 meses o maior. Assim passou até 18-7-934 (14 mezes), data em que internou-se no Serviço do Prof. Alves de Lima; aí, o exame radiológico do estômago e duodeno revelou "úlcera do bulbo doudenal" Fbi operado pelo Dr. Correia Neto, que praticou uma gastro-êntero-anastomose transmesocólica posterior a von Hacker. Alta, curado, em 5-8-934.

Após a operação, passou bem por 6 meses. Depois dêsse período, uma noite, fazendo a ronda costumeira, sentiu forte dôr, sob a forma de pontada, localizada a 4 dedos à esquerda da cicatriz umbilical, com irradiação para a fossa ilíaca esquerda. A dôr só passou quando, em sua casa, deitou-se em decúbito ventral. Desde então a dôr aparecia quasi quotidianamente, e sobretudo pela madrugada, acordando-o. Os períodos de acalmia nunca ultrapassavam 3 dias. A magnésia, os chás, as eructações, melhoravam a dôr. Quando muito forte, só conseguia alívio assumindo decúbito ventral, e comprimindo fortemente a região dolorosa.

Resolvẹu então procurar esta Santa Casa, internando-se em 6-1-1936 na 3. ${ }^{\mathrm{a}}$ C. $\mathrm{H}$.

Interrogatório sôbre os diferentes aparelhos: $1-!+1$
Antecedentes pessoais, faniliares e hereditários: $1-1$

Exame físico geral: -1

Exame físico especial - Abdômen: Nota-se uma cicatriz linear, xifoumbilical, correspondente a incisão operatória. A palpação superficial não 
desperta dôr. À palpação profunda, percebe-se, a um dedo acima da cicatriz umbilical, à direita da linha mediana, um degrau (grande curvatura), pouco doloroso, que é mais evidente e mais soloroso à esquerda da linha mediana. A um dedo abaixo da cicatriz umbilical, palpa-se outro degrau (cólon transverso), móvel, pouco doloroso.

\section{Exames de laboratório e subsidiários:}

Tempo de sangria: 3 '.

Tempo de coagulação: ' 7 '

Exame de urina (tipo 1) : $1-1$

Exame de fezes: ovos de tricocéfalos.

Reação de Wassermann: $|-|$

Reserva alcalina: $54,09 \% \mathrm{VCO}^{2}$.

Quimismo gástrico: A fig. 1 representa a curva obtida na prova de Katsch-Kalk. Líquido de estase: 40 cc., amarelo-esverdeado, com muito muco, sem detritos alimentares. Ao exame microscópico, raros letıcocitos e celulas epiteliais.

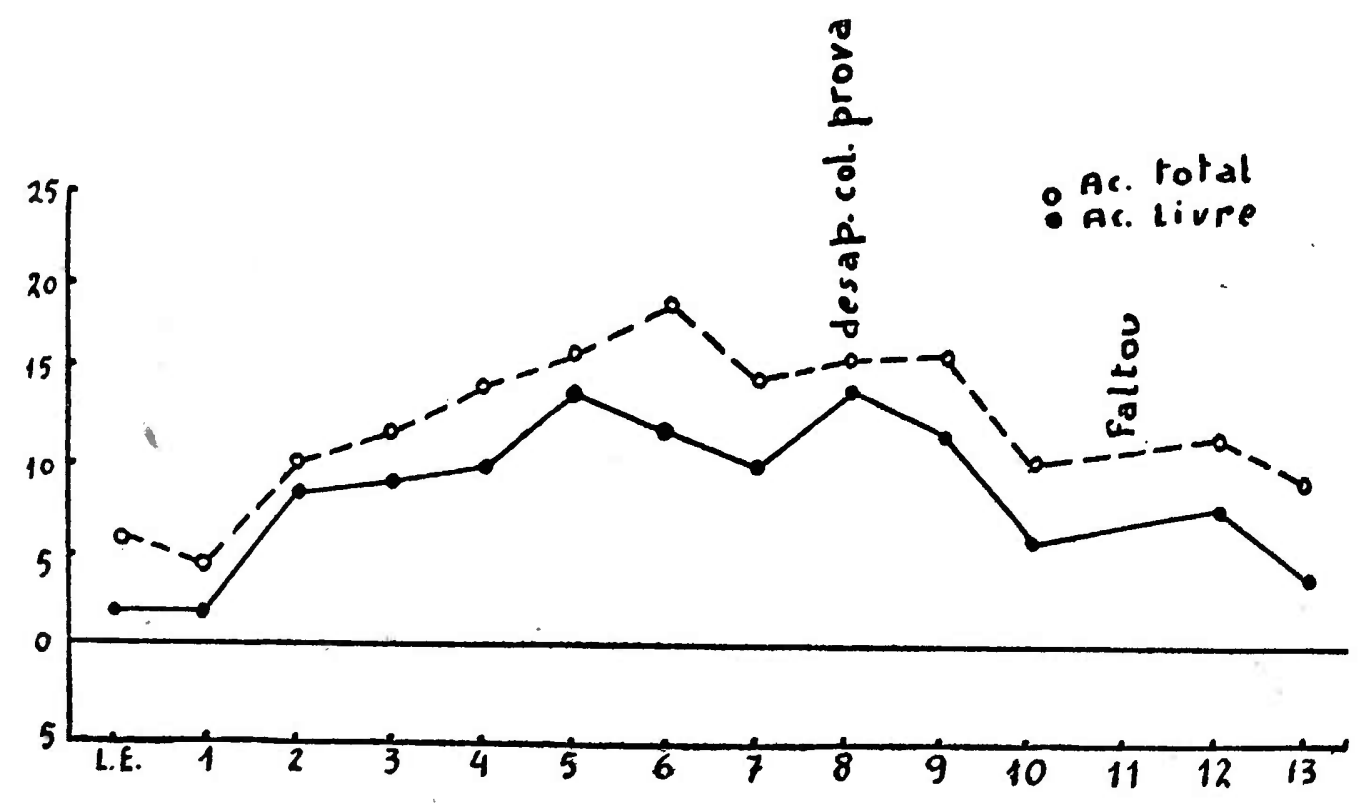

Fig. n: 1

Exame radiológico: "Pequeno nicho de úlcera na bôca anastomótica. Passagem da refeição opaca pelo piloro, com enchimento do bulbo, que se apresenta deformado. Ulcera péptica da bôca. Ulcera doudenal" 10-1-936. a) Dr. Cassio Villaça.

Operação: Após tratamento pre-operatório padrão, (aplicação diária durante 3 dias da seguinte medicação: bicarbonato de sodio, 30,0; xarope simples, 300,0; sôro glycosado isotorino, 1 lt. ; insulina, 10 unıd. ; digitalina, 25 got.), em 16-11936 foi operado pelo Pró. Correia Neto.

Anestesia: raquidiana (percaina).

Incisão mediana xifo-umbilical. São desfeitas aderências do peritônio parietal com o cólon transverso e grande epíploon; dêste, com alças intestinais e mesocólon. Liberada a bôca anastomótica, verifica-se a existência de 


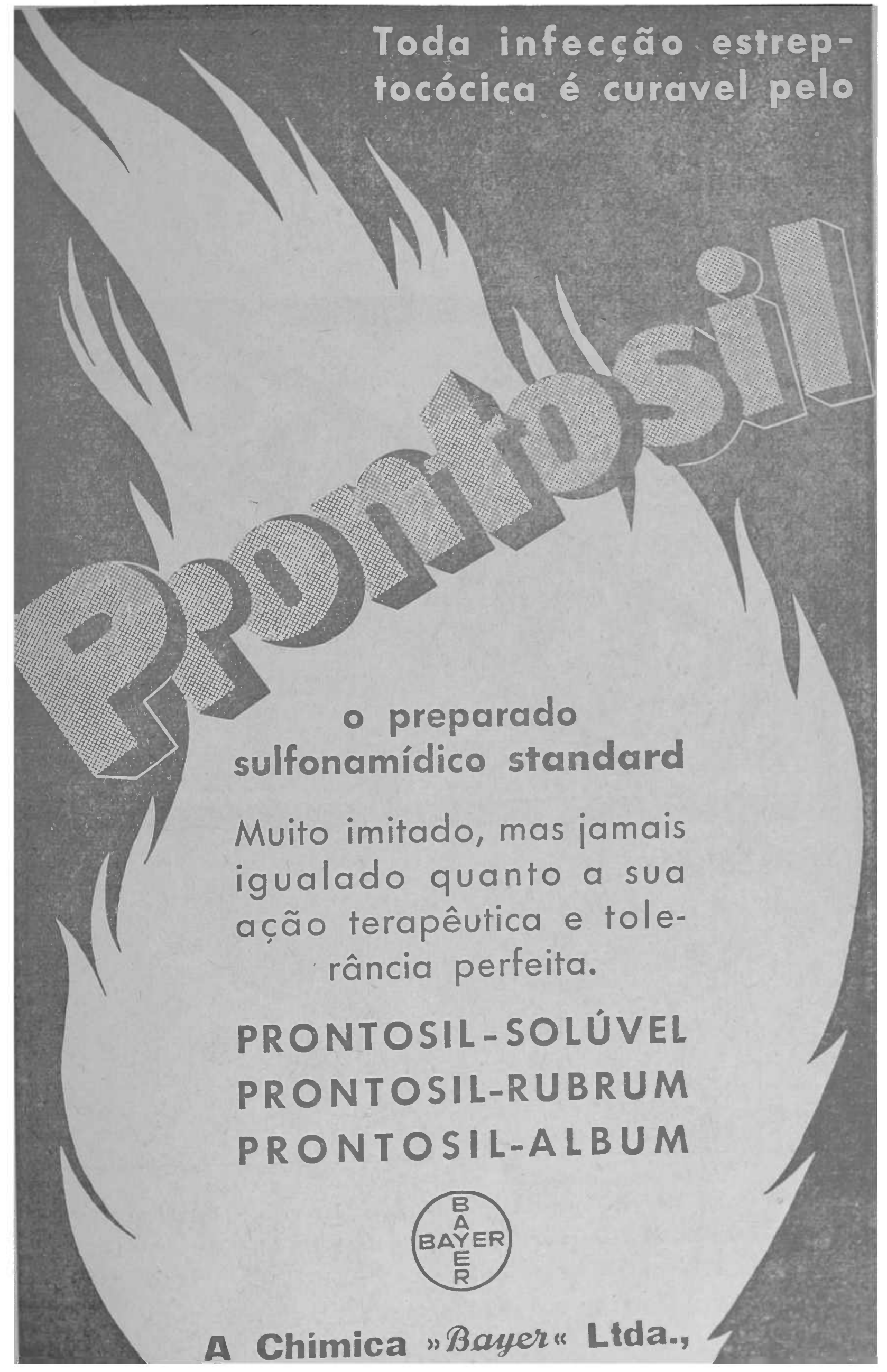




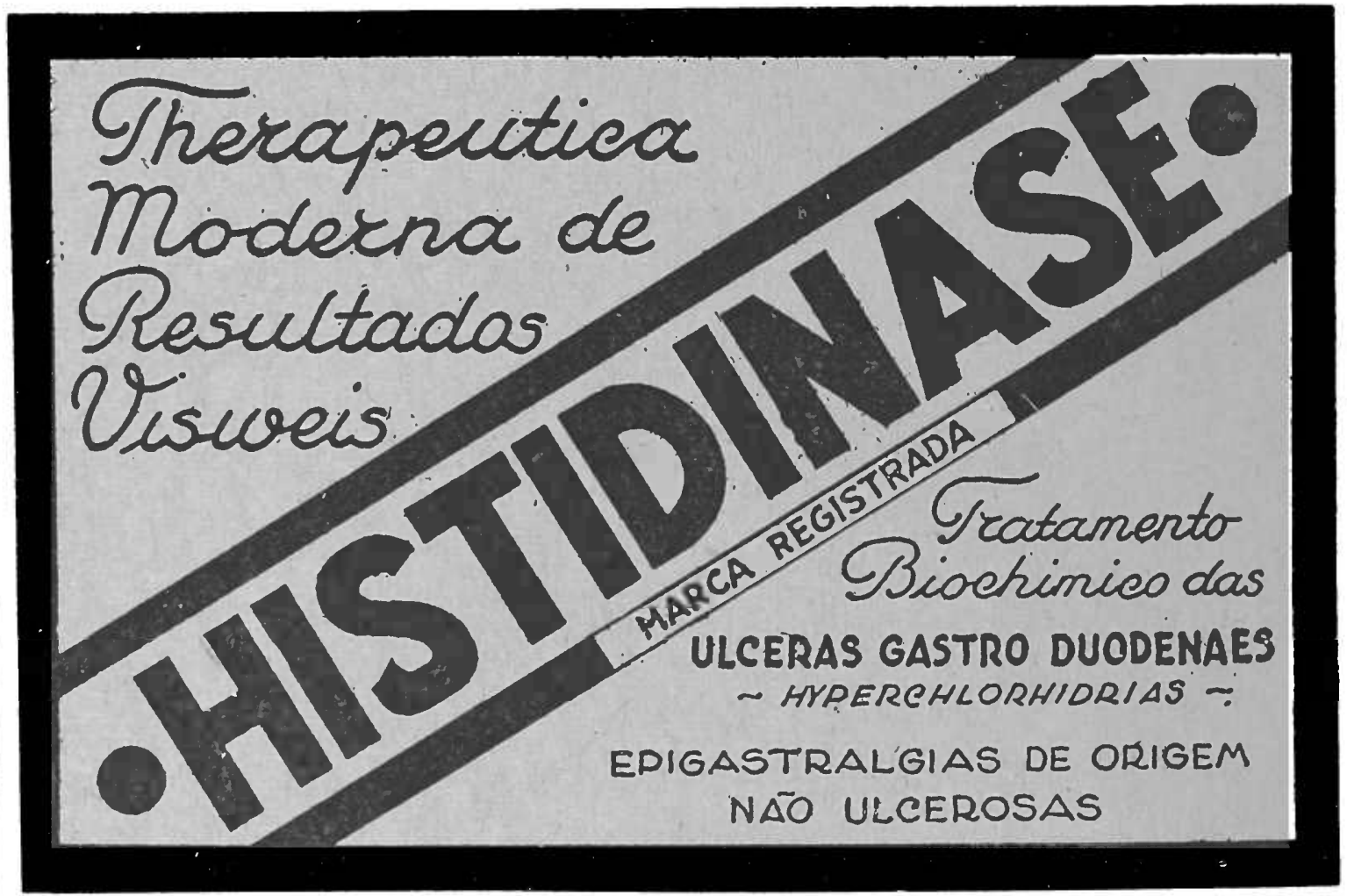

Os pedidos de Amostras e Literatura devem ser dirigidos: ESTADO DE S. PAULO: J. PELOSI - CAIXA POSTAL, 2881 - S. PAULO RIO DF JANEIRO e outros Estados do Brasil: SCHILLING, HILLIER \& CIA. LIM. - CAIXA POSTAL, 1030 RIO 
uma cicatriz na sua face posterior. Secção de aderências que prendem o piloro e a primeira porção do doudeno, à face inferior do fígado, ao cólon transverso, grande epíploon e mesocólon. Laqueadura da alça jejunal a montante e a juzante da bôca, e secção da mesma, fechando-se os côtos úteis com clamps de coprostase. Jejuno-jejuno-anastomose término-terminal em 2 planos, com cat-gut 00 simples. Libertação da grande curvatura, em extensão conveniente. Ligadura da artéria pilórica. Ligadura e secção do doudeno. Sepultamento do côto doudenal. Ligadura da artéria coronária. Fixação do lábioesquerdo da brecha mesocólica na face posterior do estômago. Reconstituição do trânsito, por anastomose término-lateral transmesocólica do estômago à primeira alça jejunal, a juzante de anastomose jejuno-jejunal. Fixação do lábio direito da brecha mesocólica à face anterior do estômago. Fechamento da parede por planos. - A fig. n.o 2 representa a fotografia da peça operatória.

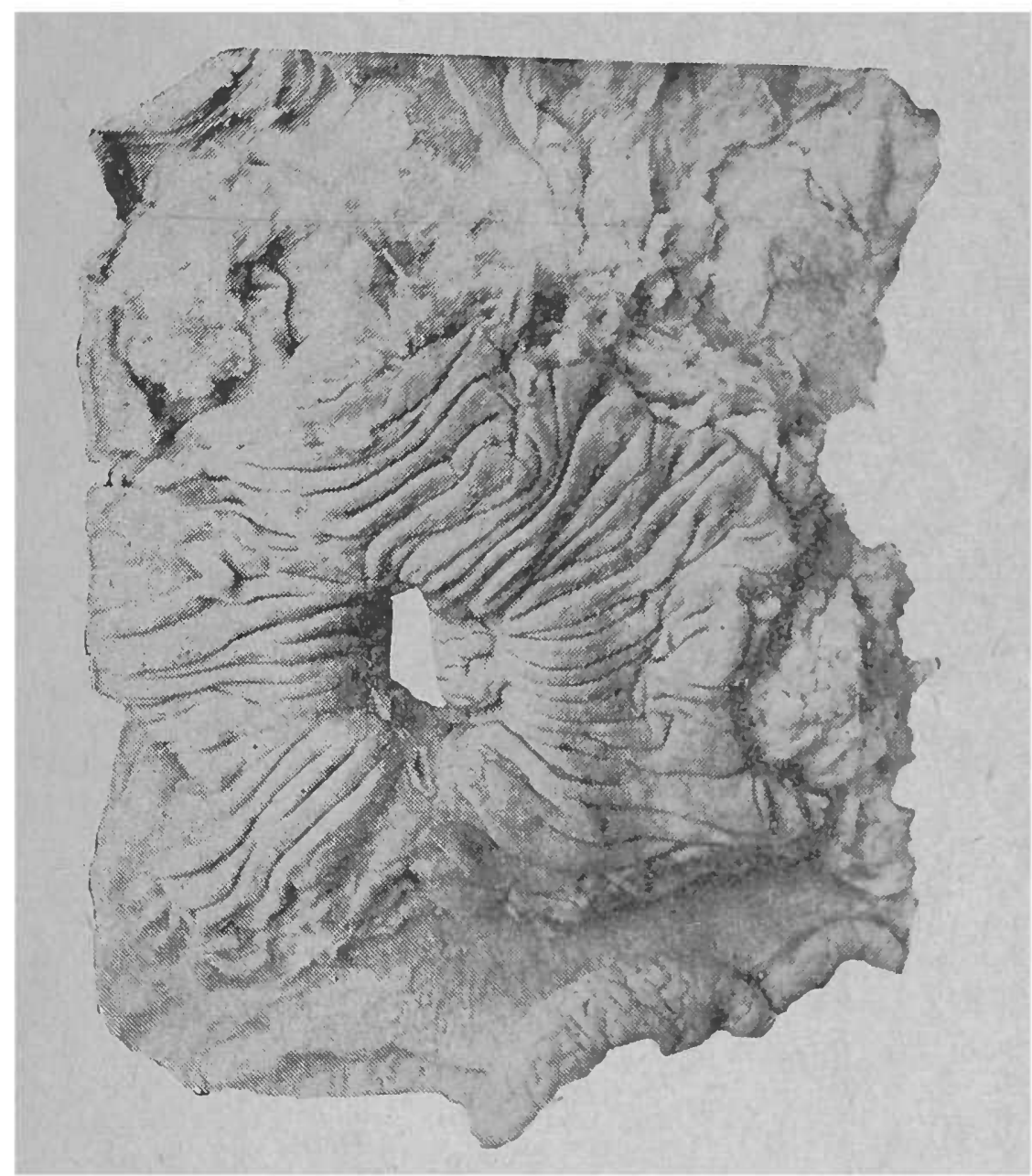

FIG. 2

Post-operatório: Nada de anormal. - Alta, curado, em 26-1-936.

Follow-up: Voltou em 11-1-938, queixando-se de dôres no epigástrio que passam com a ingestação de alimentos; azia e sialorréa. Estes sintomas surgiram um ano após a operação.

Para verificar as condições atuais, é solicitado exame radiológico: "Gastrectomia com ressecção do antro e parte do corpo gástrico. Desenho da mucosa do estômago e jejuno espessado. Não foi observada sombra ou nicho de úlcera no estômago ou alça jejunal anastomosada" 14-1-938. a) Dr. Ignacio L. Alves Corrêa. 


\title{
OBSERVAÇÃO N. ${ }^{\circ} 2$
}

P. C., 30 anos, branco, brasileiro, solteiro, operário.

História pregressa da moléstia atual: Em meados de 1924, começou a sentir dôr no epigástrio; surgia meia hora após as refeições, e só melhorava com vômitos, espontâneos ou provocados. Ao mesmo tempo, azia, eructações, prisão de ventre. Curtos periodos de acalmia (até um mês). Nestas condições passou 4' anos, findos os quais resolveu submeter-se a intervenção cirúrgica, em Catanduva, por "úlcera do estômago" (sic).

A operação de nada the valeu, pois algumas semanas após a mesma, começou a ter dôr no epigástriọ, localizada no meio da linha xifo-umbilical, com irradiação para o hipocôndrio direito e dorso. Esta dôr' aparecia de $15^{\prime}$ a 30' após as refeições. Vômitos frequentes, azedos, em quantidade. superior à das substâncias recém-ingeridas, e que sempre lhe traziam alívio. $O$ macarrão provocava maior dôr que quaisquer outros alimentos. Tinha, frequentemente, sensação de empachamento no epigástrio Raros períodos de acalmia, sendo de 7 meses o mais longo.

Nessas condições passou até 8-3-936 (8 anos), data em que deu entrada na $3 .^{\mathrm{a}} \mathrm{C} . \mathrm{H}$.

Inlerrogatório sôbre os diferentes aparelhos: $|-|$.

Antecidonles pessoais, familiares e hereditários: $1-1$

Errame fisico geral: $|-|$

Exame físico especial - Abdômen: Verifica-se a existência de uma cicatriz cirúrgica xifo-umbilical. O estômago desenha-se em elevação sob a parede, orientado da esquerda para a direita, de cima para baixo, do hipocôndrio esquerdo para o flanco direito, cruzando a linha média acima do umbigo. Observam-se contrações peristálticas lentas. A palpação profunda do epigástrio provoca ligeira dôr.

\section{Exames do laboratório e subsidiários:}

\author{
Tempo de sangria: 2' \\ Tempo de coagulação: 6'. \\ Exame de urina (tipo 1): $|-|$ \\ Exame de fezes: -1 \\ Reação de Wassermann: \\ Reserva alcalina: $50.07 \% \mathrm{VCO}^{2}$.
}

Quimismo gástrico: A fig. 3 representa a curva que se obteve na prova de Katsch-Kalk. Líquido de estase: 94 cc., amarelo-esverdeado, sem cheiro, sem resíduos alimentares, espesso, com muito muco. O exame microscópico revela grande número de leucocitos, muitas celulas epiteliais, grande quantidade de muco e ausência de sangue.

Exame radiológico: "Úlcera péptica do jejuno. Úlcera do piloro. Úlcera do bulbo duodenal". 12-3-936 a) Dr. Cassio Villaça.

Opcração: Em seguida a um tratamento pré-operatório padrão, foi operado em 17-3-936 pelo Prof. Correia Neto.

Ancstesia: raquidiana (escurocaina).

Laparotomia mediana supra-umbilical. Ao ser desfeita forte aderência do jejuno ao cólon transverso, abre-se a úlcera jejunal. É ressecado o segmento jejunal em que se encontra a bôca anastomótica, numa extensão de $10 \mathrm{cms}$. Jejuno-jejuno-anastomose término-terminal. Libertação do estômago e pri- 
meira porção do duodeno, pela ligadura de vasos e secção de aderências. Ligadura e secção do duodeno. Sepultamento do côto duodenal. Fixação do lábio esquerdo da brecha mesocólica à face posterior do estômago. Anastomose término-lateral transmesocólica do estômago na primeira alça jejunal, a juzante da jejuno-jejunostomia. Fixação do lábio direito da brecha mesocólica à face anterior do estômago.

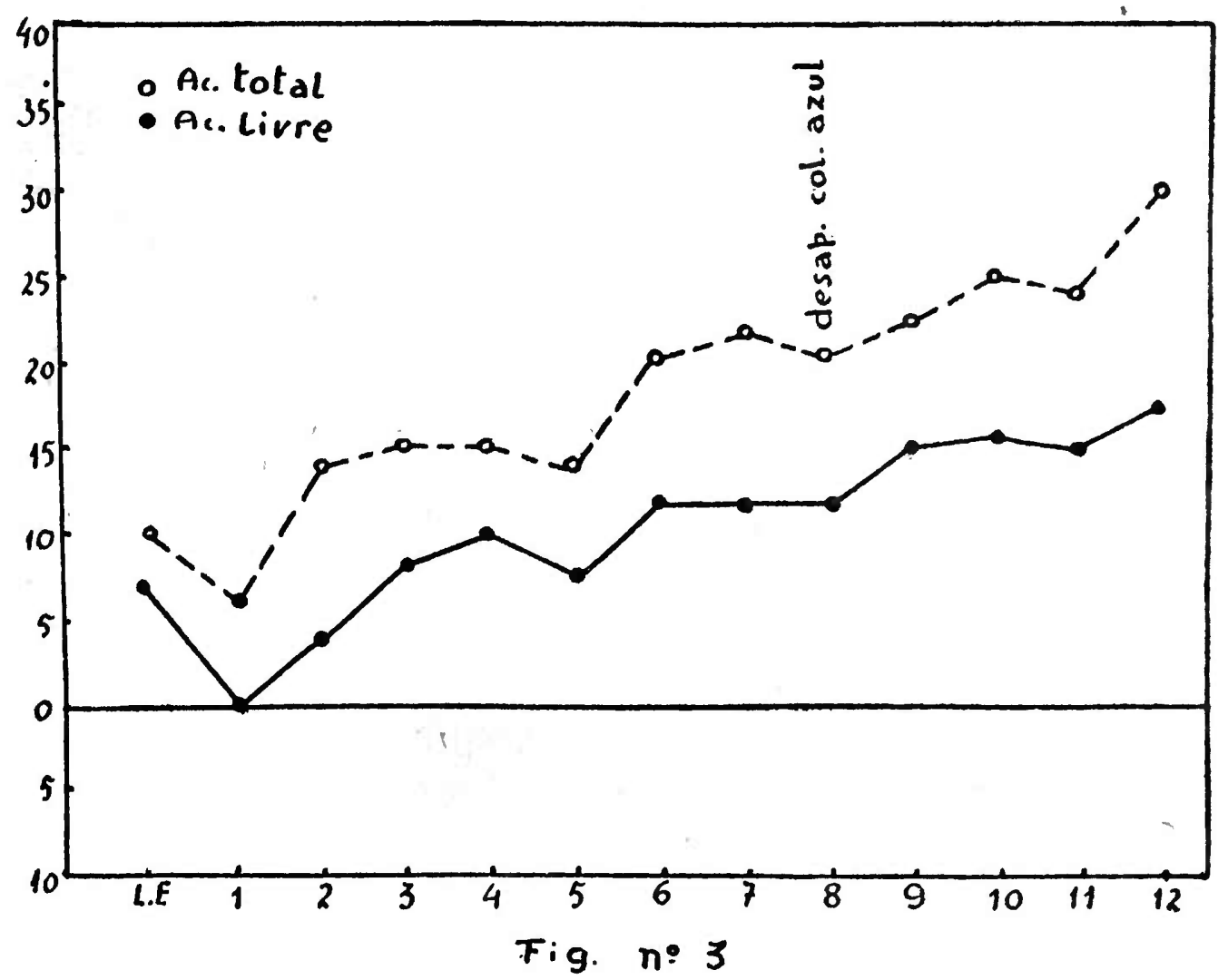

Fechamento da parede em um plano, peritônio-aponevrótico. Agrafes na pele.

Post-operatório: Acidentado. No dia seguinte, morte do paciente.

Autópsia: Peritonite fibrino-purulenta generalizada.

\section{OBSERVAÇÃO N.॰ 3}

A. F., 40 anos, branco, italiano, casado, marceneiro.

História pregressa da moléstia atual: Em meados de 1921 começou a ter queimação no epigástrio, que aparecia 3 a + horas após as refeiçocs e cessava com a ingestão de alimentos. Passados 2 anos, a. queimação foi substituida por dôr epigástrica; dôr tardia, irradiada para os flancos. melhorada com vômitos e ingestão de alimentos. Azia, eructações, prisĩo de ventre. Períodos de acalmia longos, chegando a $t$ anos. Emagreceu 8 quilos. Assim passou até 6-2-936 (15 anos), quando deu entrada tla $3 .^{\text {a }}$ C. II. O exame radiológico, feito pelo Dr. Cassio Villaça, rucelou "úlcera do huibu duntenal" Em 20-3-936 foi operado pelo Dr. Otávio Martins Tolerin, que praticun uma gastro-êntero-anastomose transmesocólica posterior a ron Hactir. Hunce deiscência da sutura da parede, consequente a supuraçióo da mo-mi. Em 1s-t936 teve alta, curado. 
Em 14-7-936, o paciente voltou ao mesmo Serviço, queixando-se de dôr na metade esquerda da porção inferior da região umbilical e superior da hipogástrica. Esta dôr apareceu há 3 meses; surge 2 a 4 hoas após a ingestão de alimentos, atinge $o$ acme em poucos minutos, e generaliza-se a todo o abdômen, sob a forma de intensa cólica. Só conseguia alívio quando se deitava em decúbito dorsal; ao cabo de meia hora, nada mais sentiá. Não acusava nenhum outro sintoma.

Interrogatório sôbre os diferentes aparelhos: $|-|-\mid$
Antecedentes pessoais, familiares e hereditários: $|-|$

Exame físico geral: $|-|$

Exame fisico especial - Abdômen: Observa-se uma cicatriz cirúrgica xifoumbilical. Há eventração supra-umbilical da parede abdominal. A palpação profunda desperta dôr no epigástrio.

Exames de laboratório e subsidiários:

Tempo de sangria: 2'30.

Tempo de coagulação: $10^{\prime}$.

Exame de urina (tipo 1): $|-|$

Exame de fezes: $|-|$

Uréa no sangue: 0,34 .

Reserva alcalina: $60,30 \% \mathrm{VCO}^{2}$.

Exame radiológico: "Ulcera péptica do jejuno; nicho na alça eferente, a $2 \mathrm{cms}$. da bôca. Esvaziamento pelo piloro e pela anastomose. Bulbo com pequeno nicho de úlcera em cicatrização". 10-7-936. a) Dr. Cassio Villaça.

Operação: Após tratamento pre-operatório padrão, foi aperado em 18-7-936 pelo Prof. Correia Neto.

Anestesia: peridural.

Incisão supra-umbilical, fusiforme, marginando a anterior. São desfeitas aderências de alças intestinais ao peritônio parietal. A bôca anastomótica encontra-se permeável. São desfeitas aderências do grande epíploon, mesocólon, etc. Libertação do estômago e duodeno. Ligadura e secção do duodeno. Sepultamento do coto duodenal. Secção da alça jejunal, a $4 \mathrm{cms}$. a montante e a juzante da bôca. Anastomose jejuno-jejunal término-terminal. Secção da coronária entre 2 ligaduras. Fixação do lábio esquerdo da brecha mesocólica na face posterior do estômago. Reconstituição do trânsito, por anastomose gastro-jejunal término-lateral transmesocólica, feita a juzante da bôca anastomótica. Fixação do lábio direito da brecha na face anterior do estômago. Fechamento da parede, por planos.

A fig. n. 4 mostra a fotografia da peça operatória,

Post-operatório: Nada de anormal. Alta, curado, em 28-7-936.

Follow-up: Em 26-9-938 o paciente voltou a êste Serviço. Sentia-se perfeitamente bem. Para verificar as condições atuais, foi pedido exame radiológico, que revelou: "Gastrectomia parcial: exclusão do antro e parte inferior do corpo gástrico. Ausência de sinais de nicho ulceroso. Esvaziamento em tempo normal". 4-10-38. a) Dr. Cassio Villaça.

\section{OBSERVAÇÃO N. ${ }^{\circ} 4$}

D. P., 27 anos, branco, brasileiro, casado, operário.

História pregressa da moléstia atual: $\mathrm{E}_{\mathrm{m}}$ meados de 1931, começou a sentir dôr no epigástrio; essa dôr localizava-se particularmente no meio da 
linha xifo-umbilical, aparecendo 2 a 3 horas após as refeições. A ingestâo de alimentos the trazia completo alívio. Ás vezes, a dôr surgia pela madrugada. Concomitantemente, vômitos, eructações, sialorréa; constipação. Assim passou até 30-6-933 (2 anos) data em que deu entrada neste Serviço. Exame radiológico: "úlcera do bulbo duodenal". 2-7-933. a) Dr. Paulo de Almeida Toledo. Em 15-7-933 foi operado pelo Prof. Correia Neto, que praticou uma gastrectomia parcial a Hoffmeister-Finsterer. Alta, curado, em 30-7-933.

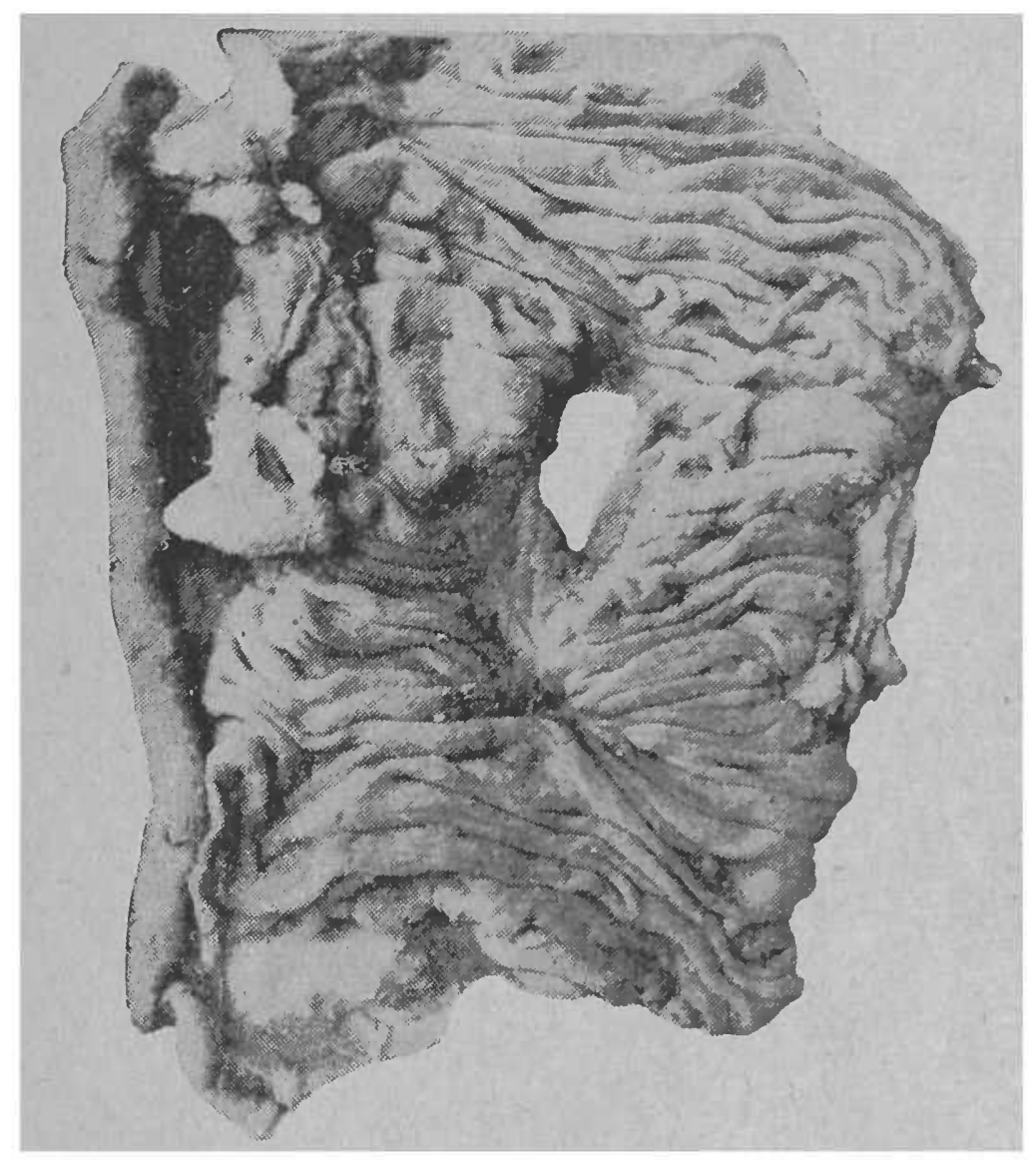

FIG. 4

$E_{\mathrm{m}}$ 7-7-937, o paciente voltou à $3 .^{\mathrm{a}} \mathrm{C} . \mathrm{H}$. Diz que passou bem 3 anos após a operação. Sobrevieram depois os mesmos sintomas, mais ou menos com os mesmos caracteres: dôr epigástrica post-prandial, tardła, que desaparece com a ingestão de alimentos; vômitos, sialorréa, constipação.

Interrogatório sôbre os diferentes aparelhos: $|-|$

Exame físico geral:

Exame físico especial - Abdômen: Verifica-se a existência de uma cicatriz cirúrgica correspondente a incisão supra-umbilical para-mediana direita. A palpação profunda desperta dôr no epigástrio.

\section{Exames de laboratório e subsidiários:}

Tempo de sangria: 2'30.

Tempo de coagulação: 10 '.

Exame de urina (tipo 1): $|-|$

Exame de fezes: -1

Taxa de hemoglobina: $80 \%$. 
Exame radiológico: "Nicho de úlcera jejunal ná alça eferente, a $2 \mathrm{cms}$. da bôca, com dôr acentuada à pressão. Depósito de contraste ao nível da bôca, sensível à pressão (nicho?). Gastrectomia parcial. Exclusão do antro. Esvaziamento em tempơ normal. Mucosa do estômago espessada" 14-7-937. a) Dr. Cassio Villaça.

Operação: Após tratamento pré-operatorio padrão, o paciente foi operado em 22-7-937, pelo Prof. Correia Neto.

Anestesia: peridural (novocaina a $2 \%: 50 \mathrm{cc}$.).

Incisão mediana xifo-umbilical. São desfeitas adêrencias do grande epíploon com o peritônio parietal e face inferior do fígado. O exame da bôca revela a existência de 2 úlceras, uma na alça aferente, outra na alça eferente. São desfeitas aderências da bôca ás estruturas vizinhas. Ressecção da bôca anastomótica, inclusive pequena extensão do jejuno, de cada lado. Anastomose jejuno-jejunal término-terminal. Fixação do lábio esquerdo da brecha mesocólica na face posterior do estômago. Anastomose gastro-jejunal término-lateral, do estômago na $1 .^{\mathrm{a}}$ alça jejunal, a juzante da jejuno-jejunostomia. Fixação do lábio direito da brecha mesocólica na face anterior do estômago. Fechamento da parede em 3 planos.

Post-operatório: Nada de anormal. Alta, curado, em 1-8-937.

Follow-up: Em 28-7-938, o paciente voltou ao Serviço. Sente-se perfeitamente bem. E solicitado exame radiológico, para constatação das condições atuais: "Gastrectomia parcial. Exclusão do antro è parte do corpo gástrico. Esvaziamento normal" 30-7-938. a) Dr. Cassio Villaça.

\section{OBSERVAÇÃO N. ${ }^{\circ} 5$}

F P. R., 24 anos, branco, braisleiro, solteiro, trabalhador rural.

História pregressa da moléstia atual: Em princípios de 1934, foi operado neste Hospital pelo Dr. Eduardo Etzel, de "úlcera do estôrnago". Pasšou bem por 6 meses. Começou depois a ter azia, que sobrevinha diàriamente, não influenciada pela ingestão de alimento. Às vezes obtinha melhoras com a ingestão de bicarbonato. Nestas condições esteve 2 anos, findos os quais começou a ter dôr no epigástrio: dôr de fraca intensitlade, não influenciada pela ingestão de alimentos, não melhorada com vômitos. Aparecia quasi quotidianamente. Às vezes, cefaléas fortes e tonturas.

Interrogatório sôbre os diferentes aparelhos: $1-1$

Antecedentes pessoais:

Antecedentes familiares e hereditárias: Pai falecido por "doença do estônago" ha mais de 5 anos. Tem 5 irmãos: um deles foi operado de "úlcera do estômago"

Exame físico geral:

Exame físico especial - Abdômen: Presença de uma cicatriz cirúrgica xifo-umbilical. À palpação profunda, percebe-se um degrau pouco doloroso a um dedo acima da cicatriz umbilical.

Exames de laboratório e subsidiários:

Tempo de sangria: 2'.

Tempo de coagulação: 6'

Exame de urina (tipo 1): $|-|$ 
Exame radiológico: "Gastro-êntero-anastomose. Estômagơ de capacidade normal, contornos regulares, com relêvo da mucoṣa espessado, principalmente na porção antral e juxta-oral. Esvaziamento se fazendo bem pela bôca, enchendo a alça jejunal eferente, que apresenta espessamento da mucosa e grande nichó de úlcera, para onde converge a mucosa, a 3 dedos abaixo da bôca anastomótica; dôr à pressão. Parecé haver ligeiro esvaziamento pelo "piloro". 11-3-938. a) Dr. Ignacio L. Alves Corrêa.

Operação: Após tratamento pre-operatório padrão, foi operado em 19-3938 pelo Prof. Correia Neto.

Anestesia: Raquidiana (percaina).

Incisão mediana xifo-umbilical, fusiforme, de modo a retirar a cicatriz anterior. São desfeitas aderências do grande epíploon ao peritônio parietal, e do estômago ao fígado. Libertação da bôca anastomótica, que apresenta aderência às estruturas vizinhas. Libertação da grande e da pequena curvatura do estômago. Ao se proceder ao descolamento entre duodeno e pâncreas, aquele é perfurado. Neste ponto, o duodeno é seccionado transversalmente, e fechado por sutura em 2 planos. Secção do jejuno, de cada lado da bớca, e a pequena distância da mesma. Jejuno-jejuno-anastomose término-terminal. Fixação do lábio esquerdo da, brecha mesocólica à face posterior do estômago. Gastroêntero-anastomose término-lateral, do estômago na alça jejunal, a juzante da jejuno-jejunostomia. Fixação do lábio direito da brecha mesocólica à face anterior do estômago. Fechamento da parede.

Post-operatório: Acidentado. Choque. Morte em 22-3-938.

Autópsia: Insuficiência cardíaca.

\section{OBSERVAÇÃO N. ${ }^{\circ} 6$}

A. J. Z., 46 anos, branco, brasileiro, casado, marceneiro.

História pregressa da moléstia atual: Em princípios de 1919, começou a sentir dôr no epigástrio; esta surgia 2 a 3 horas após as refeições, e melhorava com vômitos e ingestão de alimentos. Ùltimamente, a dôr tornara-se mais intensa; às vezes, apresentava vịolentas cólicas abdominais. Eructações, azia, prisão de ventre. Períodos de acalmia: o maior foi de 8 meses. Assim passou até 1927 ( 8 anos), quando então ingressou na 2. ${ }^{a}$ C. H. Aí, foi operado pelo Prof. Alves de Lima, que praticou uma gastro-êntero-anastomose.

Passou perfieitamente bem até meados de 1937 (10 anos). Depdis, começou a sentir dôr localizada a um dedo acima e a um dedo à direita da cicatriz umbilical; tal dôr sobrevinha uma a duas horas após aș refeições, atingia o acme 20 ' após o inicio, e desaparecia completamente com a ingestão de alimentos, pelo que levava sempre consigo pedaços de pão. A compressão manual sôbre a região dolorosa, bem como o decúbito dorsal, the traziam alívio. Curtos períodos de acalmia: o maior foi de 15 dias. Não houve emagrecimento. Depois de 2 anos de doença, em 11-8-939, deu entrada na 3. ${ }^{\text {a }}$. $\mathrm{H}$.

Intcrrogatório sôbre os difercutes aparclhos:

Antecedentes pessoais: 1

Antecedentes familiares $e$ hereditćrios: Irmã operada, aos 28 anos, de "úlcera do estômago". Tem 9 filhos, com saúde; o mais velho foi operado, aos 22 anos, de "úlcera do estômago"

Exame físico geral: $1-1$

Exame físico especial - Abdômen: Presença de cicatriz cirúrgica xifoumbilical. Sob a cicatriz umbilical, palpa-se um cordão não gargarejante, muito doloroso. 


\section{Exames de laboratório e subsidiários:}

Tempo de sangria: 2'5.

Tempo de coagulação: 8'.

Exame de urina (tipo 1):

Exame de fezes:

Contagem global e específica: Nada de anormal.

Taxa de hemoglobina: $86 \%$.

Valor globular: 0,8 .

Reserva alcalina: $56 \%$.

Quimismo gástrico: A fig. n. ${ }^{\circ} 5$ representa a curva obtida ná prova de Katsch-Kalk.

Exame radiológico: "Gastro-êntero-anastomose. Estômago diminuido de volume; mucosa espessada, principalmente no antro. Bulbo duodenal deformado. Espessamento da mucosa da alça jejunal ao nível e nas vizinhanças da bôca anastomótica. $\mathrm{Na}$ alça jejunal, nicho de úlcera muito doloroso á pressão. Úlcera péptica de jejuno”. 29-8-939. a) Dr. Miguel Centola.

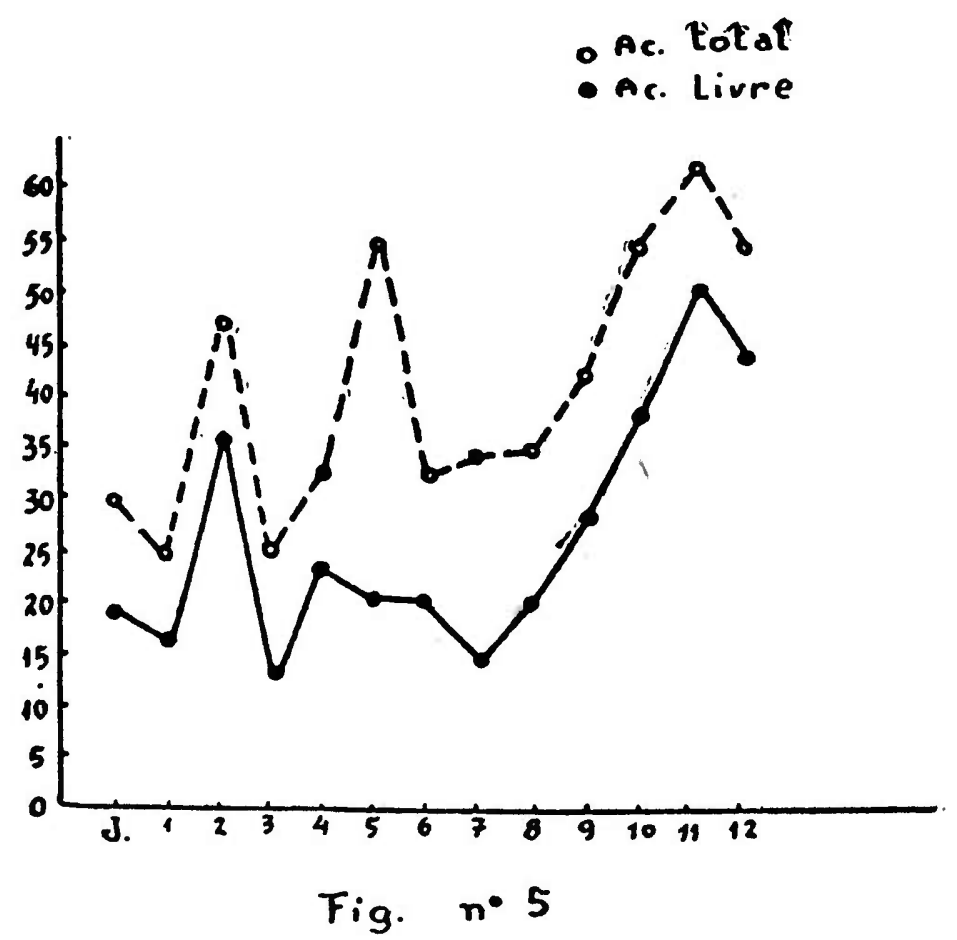

Operação: Após tratamento pre-operatório padrão, foi operado em 12-9939 pelo Prof. Correia Neto.

Anestesia: Peridural (novocaina a $2 \%-55$ cc.).

Incisão mediana supra-umbilical. São desfeitas aderências do peritônio parietal, grande epíploon, mesocólon, etc., às estruturas vizinhas. Verifica-se intensa reação inflamatória, particularmente ao nível da bôca anastomótica. Isolamento da bôca anastomótica. Secção da alça jejunal em ponto próximo à anastomose jejuno-jejunal término-terminal, em 2 planos. Libertação da grande curvatura, em extensão conveniente. Ligadura da artéria pilórica. Ligadura e secção do duodeno. Sepultamento do coto duodenal. Secção da artéria coronária, entre duas ligaduras. Fixação da brecha. Anastomose gastro-jejunal término-lateral transmesocólica, a juzante da jejuno-jejunostomia, por sutura em 2 planos com cat-gut 0 cromado. Fixação do lábio 


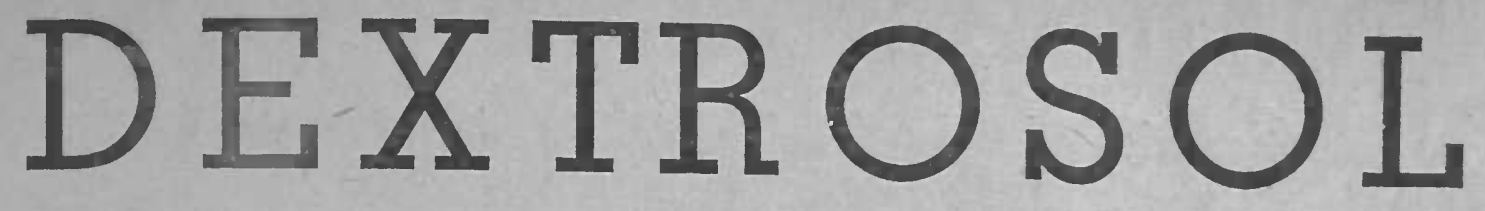

$$
\text { ( } G L U C O S E-d \text { ) }
$$

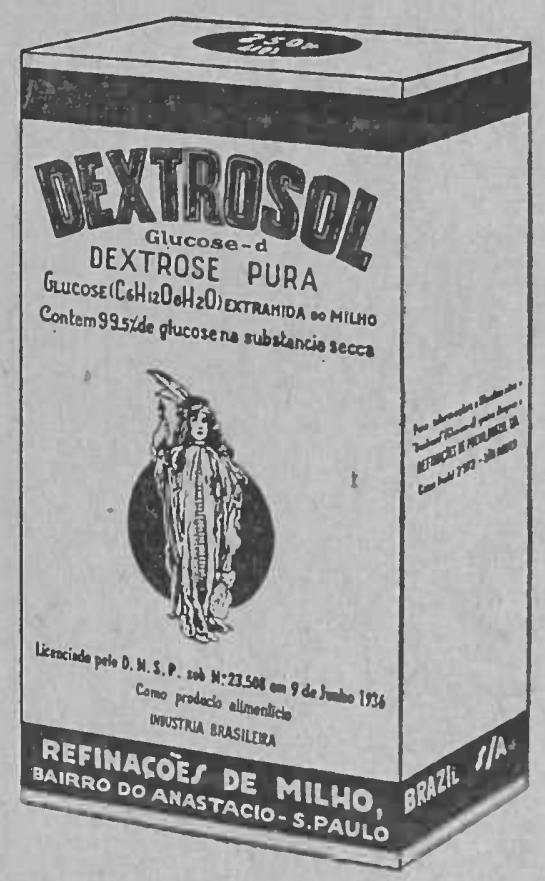

"DRENA AGUA DOS TECIDOS PARA A CIRCULAÇÃO, ELIMINANDO EDEMAS, AUMENTANDO O VOLUME SANGUINEO E PROMOVENDO A DIURESE"

E. MEYER - Usos Terapeuticos das Injeções Endovenosas de Soluções de Glucose) Zentralb. f. klin., Med. 102.343, 1925. Abst. J. A. M. A. 86.521, 1926. 


\section{LICEU PAN-AMERICANO}

(Propriedade da Escola Paulista de Medicina)

\section{EXTERNATO PARA AMBOS OS SEXOS}

Sob regimen de inspecção federal permanente pelo decr. 1.533 de 15. de Março de 1937

DIRETORES:

Drs. Alvaro de Lemos Torres e Antonio de Carvalho Aguiar CURSOS:

Pré-Primario (Jardim da Infancia)

Primario (4 anos)

Admissão ao Ginasio (I ano)

Ginasial Fundamental (5 series)

Complementar Pré-Medico (2 series)

Complementar Pré-Politécnico (2 series)

Complementar Pré-Jurídico (noturno) (2 series)

Curso de Preparação às Escolas Militares.

MAGNIFICOS LABORATORIOS DE FISICA, QUIMICA E HISTORIA NATURAL

ENSINO PRATICO INTENSIVO.

\section{LICEU PAN-AMERICANO}

R. Visconde de Ouro-Preto, 51 (Consolação)

Tel.: 4-I587

SÂO PAULO 
direito da brecha mesocólica à face anterior do estômago. Fechamento da parede, por planos.

Post-operatório: Do 2.0 bia em diante, começou a ter vômitos. Estado geral bom. Os vômitos foram se tornando cada vez mais frequentes, comprometendo assim o estado geral do paciente. Suspeita-se de interrupção do trânsito; é solicitado exame radiológico, que revelou: "A porção existente de estômago está grandemente dilatåda, retendo muito líquido em jejum. $\mathrm{O}$ conteudo gástrico não desce, mesmo por meio de manobras adequadas. Sinais radiológicos de interrupção do trânsito gastro-intestinal" 19-9-939. a) Dr. M. A. Campanario. Após duas lavagens de estômago, o paciente voltou à normalidade.

Alta, curado, em 25-9-39.

Follow-up: Em 19-4-40, voltou ao Serviço. Sente-se completamente curado, forte, tendo engordado 12 quilos.

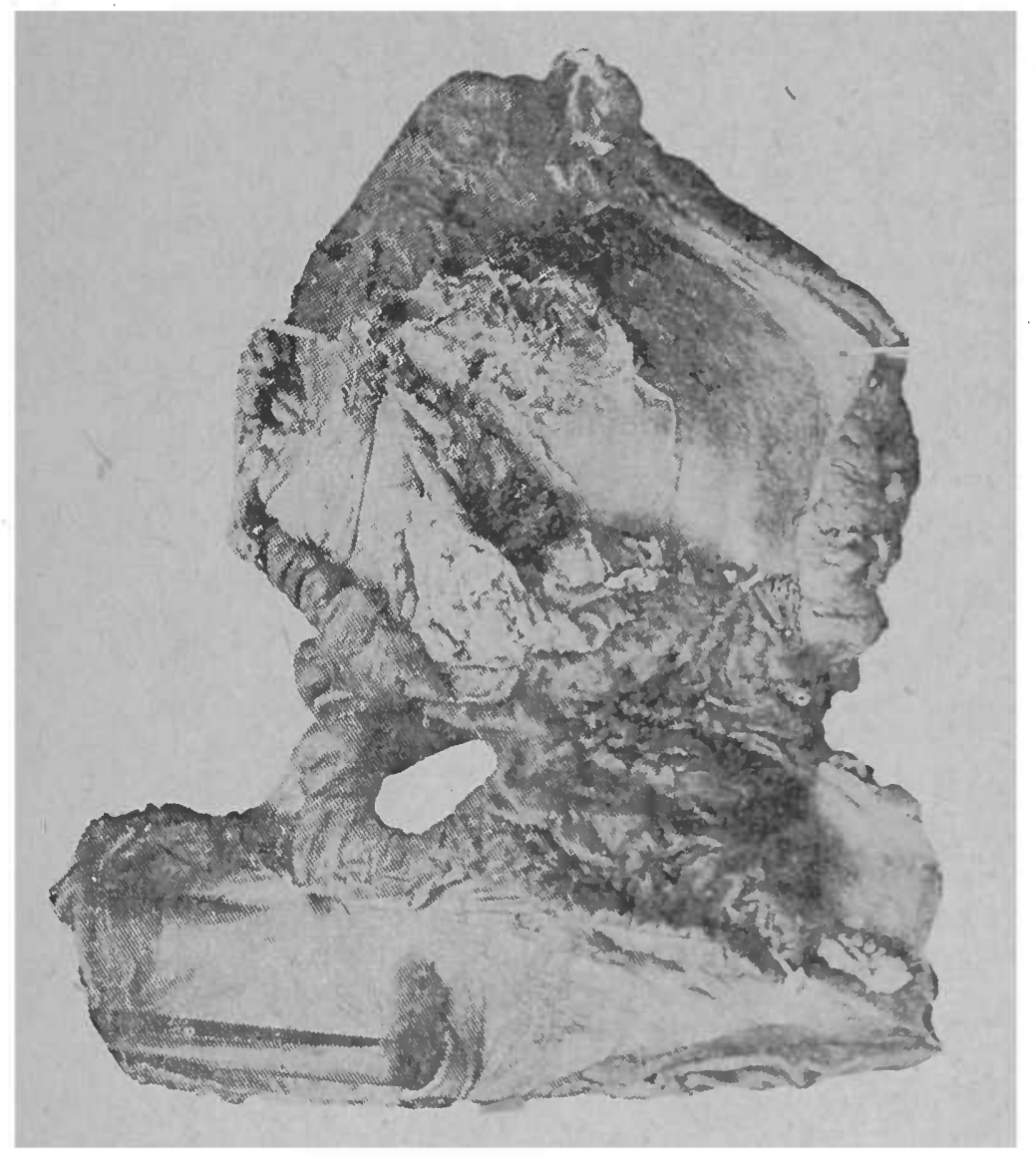

FIG. 6

Face anterior

\section{OBSERVAÇÃO N. $0^{\circ} 7$}

S. A., 28 anos, branco, casado, brasileiro, lenhador.

H. P. M. A. - Há 12 anos vem sentindo dôres no epigástrio, relacionadas com a alimentação, tardias, não irradiadas. Ao mesmo tempo, azia, que aparecia e desaparecia com dôr; pêso no epigástrio. Ausência de vômitos. Com o passar dos anos, sua doença peorou; agravaram-se todos os sintrmas. Há 8 anos teve uma hematemese, seguida, passadas semanas, por mais duas. Nāo apresentava aversão ou predileção por quaisquer alimentos. Foi então oṛerał!o, 
em S. Carlos, de úlcera (sic.) Ficou um mês no hospital; a operação não lhe trouxe nenhuma melhora, nem ao menos imediata. Continuaram as dôres, azia, etc. Apareceram vômitos, que sempre lhe traziam alívio. Não tinha hematemeses.

De três anos a esta data, sua moléstia modificou-se: a dôr epigástrica é muito mais fraca que dantes, e após as refeições sente intensa plenitude gástrica, só aliviada com vômitos provocados. Voltaram as hematemeses.

Neste último ano de doença, houve novo agravamento: após as refeições, sente insuportável tensão no epigástrio e região umbilical; passados 15 a 20 minutos, evacua os alimentos recém-ingeridos integros, sem a digestão dos mesmos. Vômitos frequentes. Não tem pròpriamente dôr, mas sim queimação no epigástrio.

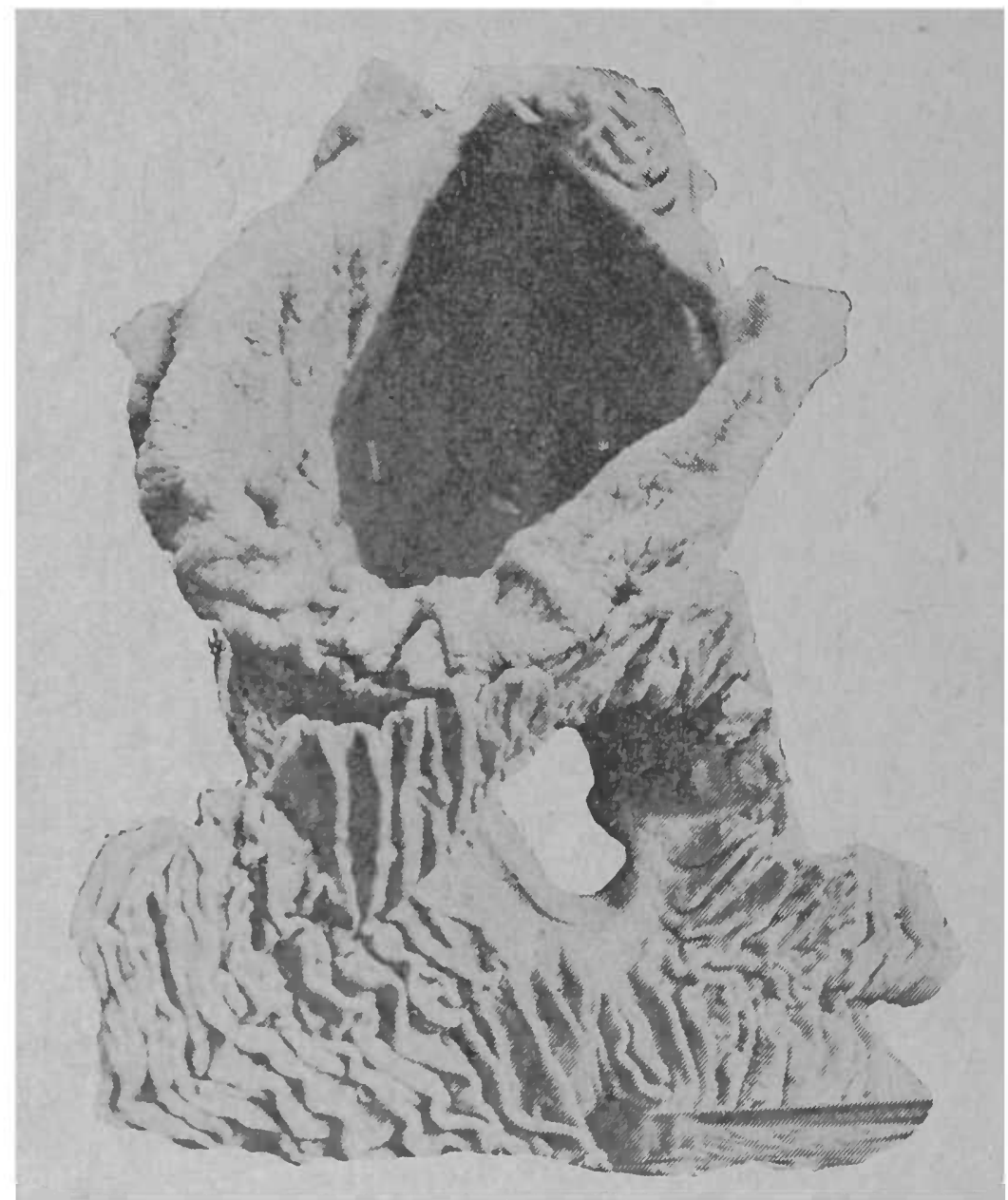

FIG. 7

Face posterior

Interrogatório sôbre os diferentes aparelhos: Tonturas frequentes; palpitaçōes.

Antecedentes pessoais, familiares e hereditários: $|-|$

Exame fisico geral: $\mid-1$

Exame físico especial - Abdômen: Presença de uma cicatriz cirúrgica xifo-umbilical. Não há peristaltismo visível. O abdômen inteiro é doloroso, ligeiramente, à palpação profunda. A região epigástrica é muito dolorosa à palpação, principalmente num ponto situado no meio da linha xifo-umbilical. 


\section{Exames de laboratório e subsidiáros:}

Tempo de sangria: 2'

Tempo de coagulação: 9'.

Exame de urina:

Exame de fezes: negativo para ovos de parasitas.

Contagem global e específica:

Reserva alcalina: $49,80 \mathrm{VCO}^{2}$.

Quimismo gástrico: Hipocloridria.

Exame radiológico: "Gastro-êntero-anastomose. Provável ligadura do piloro. Grande nicho de úlcera péptica na alça jejunal anastomosada. Fístula gastro-jejuno-cólica ao nível da ulceração. Estenose inflamatória do cólon transverso ao nível da fístula. A refeição opaca se dirige em parte diretamente para o cólon, em parte para as alças delgadas e para o ceco ascendente, onde estaciona em virtude da estenose mencionada do transverso. Com o enteroclisma, consegue-se o enchimento retrógrado do estômago" 21-10-937. a) Dr. Paulo de Almeida Toledo.

Pré-operatório: Foi feito tratamento pré-operatório conveniente ao caso, no qual é de ressaltar o tratamento reconstituinte (vitaminas $A$ e $B$, transfusão de sangue; prontosil), com o que procurou-se melhorar o precário estado geral a que a doença levara o paciente. Três dias antes da operação, foram injetados no peritônio: $20 \mathrm{cc}$. de vacina de Steinberg $(200.000 .000 \mathrm{ba}$ cilos coli por $c c$.). Esta injeção provocou intensa reação (vômitos, dôres abdominais intensas, ligeira defesa da parede).

1 Operação: Em 24-11-937, foi operado pelo Prof. Correia Neto. Anestesia peridural, com solução de novocaina a $2 \%$, injetados $55 \mathrm{cc}$, punção entre L1-L2. Resultado satisfatório.

Incisão mediana supra-umbilical. Aberto o peritônio, verifica-se a presença de muitas aderências entre a grande curvatura gástrica, o cólon e a alça jejunal curta. O peritônio é de aspecto avermelhado escuro, contendo grande quantidade de um líquido hemorrágico turvo. O plano geral da operação cifra-se em liberar a bôca anastomótica das aderências que a circundam, seccionar o jejuno antes e depois da anastomose, e restabelecimento do trânsito jejunal por sutura término-terminal. Idêntica conduta é seguida em relação ao cólon transverso. É verificada a existência de uma úlcera cicatrizada estenosante no duodeno, com abundante fibrose e intensa periviscerite ocasiosando açentuada retração da pequena curvatura. Esse tempo é sobremodo difícil. O coto duodenal é suturado em pontos separados e recoberto com peritônio vizinho. $\mathrm{O}$ estômago é seccionado, sendo praticada anastomose gastrojejunal precólica a Hoffmeister-Finsterer. Fechamento da parede com embricamento aponevrótico pela técnica Correia Neto. Não se drenou.

Duração da operação: 2 horas e 45 minutos.

As figuras 6 e 7 mostram o aspecto da peça operatória.

Evolução: O paciente foi atentamente vigiado. No dia da operação, notou-se bigeminismo com extrasístoles. Pressão fırme, ao redor de 120-80. Pulso 80. Abdômen flácidc. No dia seguinte, ás 3 horas da madrugada, acordou repentinamente, agitadíssimo, e faleceu em poucos instantes.

Autópsia: Peritonite fibrino-purulenta difusa.

Nota: A peritonite deve atribuir-se, provavelmente, à vacina contra bac. coli Steinberg, feita dois dias antes da operação. 